\title{
KOMUNIKASI TRANSBUDAYA PONDOK PESANTREN: KAJIAN TEORETIS DALAM PARADIGMA KONSTRUKTIVIS
}

\author{
Kun Wazis \\ Dosen IAIN Jember \\ Mahasiswa Program Doktor Ilmu Komunikasi Universitas Padjadjaran \\ Email: kunwazis@gmail.com
}

\begin{abstract}
An intercultural communication that occurs in a boarding school (pesantren) environment is a unique phenomenon. A number of pesantrens in Indonesia apply a pattern of multicultural education. Therefore, their students (santri) understand different culture of students who come from different cultural background. Through literature review and theoretical studies in constructivist paradigm, it can reveal a number of interesting scientific realities about transcultural communication of boarding schools in Indonesia. First, the students of different cultures understand each other and they make friends well during their study at the pesantren. Secondly, kyai has a strong influence in conveying messages of intercultural communication among santri by using pesantren symbols. Third, pesantren cultivation develops multicultural education based on Islamic teachings that understand plurality in human relations. Fourth, the boarding school environment can communicate a multicultural communication message through pesantren network, both national and international so they can build the spirit of togetherness in the diversity.
\end{abstract}

Keywords: Transcultural communication, Pesantren, Constructivism Paradigm

\begin{abstract}
Abstrak
Komunikasi transbudaya yang terjadi dalam lingkungan pondok pesantren merupakan fenomena yang unik. Sejumlah pesantren di Indonesia menerapkan pola pendidikan multikultural agar para santrinya memahami berbagai perbedaan budaya karena santri berlatar belakang budaya yang berbeda. Melalui kajian pustaka dan kajian teoretis dalam paradigma konstruktivis dapat mengungkapkan sejumlah realitas ilmiah menarik mengenai komunikasi transbudaya pondok pesantren di Indonesia. Pertama, santri berbeda budaya saling memahami perbedaan latar belakang santri sehingga membentuk keakraban selama mengenyam pendidikan di pesantren. Kedua, kyai memiliki pengaruh yang kuat dalam menyampaikan pesan-pesan komunikasi antarbudaya di kalangan santri dengan menggunakan simbol-simbol pesantren. Ketiga, pondok pesantren mengembangkan pendidikan multikultural dengan mendasarkan pada ajaran Islam yang memahami pluralitas (kebhinekaan) sebagai realitas yang manusiawi dan tidak perlu dipersoalkan dalam hubungan kemanusiaan. Keempat, lingkungan pondok pesantren dapat mengkomunikasikan pesan komunikasi multikultural melalui jaringan pesantren, baik nasional, maupun internasional sehingga dapat membangun semangat kebersamaan dalam perbedaan.
\end{abstract}

Kata Kunci: Komunikasi Transbudaya, Pesantren, Paradigma Konstruktivis 
Kun Wazis, Komunikasi Transbudaya Pondok Pesantren: Kajian Teoretis Dalam Paradigma..

\section{PENDAHULUAN}

Komunikasi

Transbudaya

(Intercultural Communication) di dunia Pondok Pesantren sebenarnya sudah dilakukan sejak lama. Hal ini bisa dilihat dari santri pondok pesantren yang kehidupan komunikasinya bersentuhan dengan orang-orang yang berasal dari berbagai kawasan di Indonesia yang memiliki keragaman budaya (multikultural), baik dari segi bahasa, suku, agama, budaya, dan lain sebagainya (Abdullah, 2014: 96). Dalam pandangan Huntington (dalam Samovar, 2014: 31), "hal terpenting dalam budaya meliputi bahasa, agama, tradisi, dan kebiasaan.". Pandangan tersebut mengindikasikan bahwa budaya dibentuk oleh bahasa yang digunakan seseorang, agama yang dianutnya, tradisi yang terwariskan dari generasi ke generasi, dan kebiasankebiasaan yang dipermaklumkan oleh suatu kelompok masyarakat. Setidaknya, ada sejumlah identitas yang bisa dilihat bahwa pondok pesantren telah mempraktekkan komunikasi lintas budaya tersebut.

Pertama, dari sisi bahasa. Pondok pesantren sudah terbiasa menggunakan bahasa Arab sebagai bahasa komunikasi di lingkungan pondok pesantren. Hal ini disebabkan, kitab-kitab yang diajarkan dalam seluruh kegiatan pesantren adalah berbahasa Arab, mulai Alquran, Alhadits, hingga kitab-kitab kuning. Bahkan, sejumlah pesantren, seperti Pondok Modern Gontor Ponorogo Jawa Timur mewajibkan dialog kesehariannya dengan bahasa Arab dan bahasa Inggris secara bergantian. Bagi yang ketahuan menggunakan bahasa
Indonesia, santri akan dikenakan sanksi. Pondok Modern Ittihadul Ummah Gontor Poso memberlakukan aturan ketat yang melarang santrinya berbicara menggunakan bahasa daerah dan mengutamakan bahasa Arab dan Inggris, serta diperbolehkan menggunakan bahasa Indonesia dalam beberapa kesempatan dan kepentingan (Abdullah, 2014: 121). Padahal, bahasa terikat dengan konteks budaya yang dapat dipandang sebagai perluasan budaya (Mulyana, 2014: 276).

Kedua, santri pondok pesantren berasal dari berbagai daerah di Indonesia, bahkan mancanegara. Dengan berkumpulnya mereka di dalam lingkungan pesantren, kaum santri secara otomatis akan belajar budaya yang berbeda dalam interaksi sosial di ranah komunitas pesantren. Perguruan Islam Pondok Tremas Pacitan Jawa Timur dihuni para santri dari Sumatera, Jawa, Kalimantan, Bali, hingga Papua. Pesantren Al Islah Bondowoso Jawa Timur sudah terbiasa menerima santri muslim dari Singapura, sehingga komunikasi para santrinya juga terbiasa dengan perbedaan budaya. Demikian juga, pondok pesantren Nurul Islam (Nuris) di Jember menerima santri dari Thailand yang berlatar belakang budaya berbeda. Dalam kehidupan mereka, perbedaan budaya, kebiasaan, dan adat istiadat dapat melebur dalam satu tradisi pesantren. Perbedaan suku dan ras, justru bisa disatukan dalam identitas Islam yang dipelajari di Pesantren. Kebhinekaan dipandang sebagai sunnatullah, bukan perbedaan yang harus dipertentangkan. 
Ketiga, tradisi pesantren memahami multikultural. Pendidikan Multikultural di pesantren sudah terbiasa di ajarkan. Untuk itu, kehidupan pesantren terjauh dari konflik karena selain perbedaan bahasa, perbedaan adat istiadat karena berangkat dari wilayah yang berbeda, pendidikan multikultural juga diajarkan di pesantren. Pendidikan sebagai kekuatan mainstream yang dikomunikasikan di pesantren menjadikan para santri sangat memahami perbedaan yang harus dipelihara, bukan menjadi sumber konflik. Pendidikan yang diajarkan di pesantren, seperti kehidupan Rasulullah SAW yang membangun masyarakat Madinah yang berpenduduk multikultural (Yahudi, Nasrani, dan Musyrik) dan hidup rukun berdampingan adalah bukti bahwa kehidupan pesantren terbiasa dengan model komunikasi Trans Budaya. Hal ini menegaskan bahwa bangunan wawasan ,kebangsaan yang menjunjung tinggi nilai-nilai egalitarian, pluralitas, multikultural, humanis, dan inklusif, tidaklah jauh dari semangat keislaman (Dalmeri, 2015: 87).

Keberagaman

budaya

(multikultural) tersebut pada satu sisi dapat menjadi aset budaya, namun pada dimensi lainnya dapat menjadi sumber konflik yang dapat terjadi di lingkungan pesantren. Sejumlah pondok pesantren di Indonesia mengembangkan pendidikan multikultural sebagai jembatan untuk membangun harmonisasi diantara para santri. Hanya saja, tidaklah gampang menerapkan pendidikan multikultural tersebut mengingat intensitas interaksi sosial para santri yang berbeda budaya tersebut berlangsung secara terusmenerus dalam lingkungan pondok pesantren. Peran kyai yang sangat sentralistik menjadi penentu penyampaikan pesan-pesan pendidikan multikultural itu untuk disalurkan kepada para santrinya. Pertanyaan tentang bagaimana komunikasi kyai terhadap santri dalam menyampaikan pesan-pesan komunikasi multikultural dapat menjadi kajian ilmiah yang menarik. Penulis mendeskripsikan fenomena komunikasi transbudaya pondok pesantren tersebut melalui dua hal, yakni kajian pustaka terhadap komunikasi transbudaya pesantren dan kajian teoretis tentang komunikasi kyai terhadap santri dalam mengembangkan pendidikan multikultural.

\section{A. Komunikasi}

Multikultural

\section{Pesantren}

Dalam memahami sikap (pesan komunikasi) santri berbeda budaya terhadap pesan kyai dalam komunikasi multikultural. Pendapat West \& Turner (2015: 5-7) dapat digunakan untuk menjelaskan realitas tersebut. Menurut West komunikasi (communications) didefinisikan sebagai proses sosial di mana individu-individu menggunakan simbol-simbol untuk menciptakan dan menginterpretasikan makna dalam lingkungan mereka. Dalam perspektif ini, ada lima istilah yang disampaikan West untuk membaca realitas komunikasi, yakni sosial, proses, simbol, makna, dan lingkungan yang 
Kun Wazis, Komunikasi Transbudaya Pondok Pesantren: Kajian Teoretis Dalam Paradigma..

saling terkait dalam memahami realitas komunikasi.

Pertama, komunikasi secara sosial diinterpretasikan bahwa komunikasi selalu melibatkan manusia serta interaksi, yakni komunikasi selalu melibatkan dua orang yang berinteraksi dengan berbagai niat, motivasi dan kemampuan. Kedua, komunikasi sebagai proses berarti komunikasi bersifat berkesinambungan dan tidak memiliki akhir. Komunikasi juga dinamis, kompleks, dan senantiasa berubah. Ketiga, simbol adalah sebuah label arbitrer atau representasi dari fenomena. Kata adalah simbol untuk konsep benda. Simbol konkret merupakan simbol yang merepresentasikan sebuah objek, sedangkan simbol abstrak merepresentasikan sebuah ide atau pemikiran. Keempat, makna adalah yang diambil orang dari suatu pesan, dimana pesan dapat memiliki satu makna dan bahkan berlapis-lapis makna. Tanpa berbagi makna, kita semua akan mengalami kesulitan dalam menggunakan bahasa yang sama atau dalam menginterpretasikan suatu kejadian yang sama. Kelima, lingkungan adalah situasi atau konteks dimana komunikasi terjadi. Lingkungan terdiri atas beberapa elemen, seperti waktu, tempat, periode sejarah, relasi, dan latar belakang budaya pembicara dan pendengar.

West memaknai komunikasi lintas budaya (intercultural communications) merujuk pada komunikasi antara individu-individu yang berlatar belakang budaya yang berbeda. Individu-individu ini tidak harus selalu berasal dari negara yang berbeda. Di negara yang penduduknya beragam seperti Amerika Serikat, kita dapat mengalami komunikasi lintas budaya dalam sebuah negara bagian, sebuah komunitas, dan bahkan dalam satu blok. Bukan merupakan hal yang aneh lagi di dalam masyarakat apabila ada dua orang yang berbeda budaya berbicara satu sama lain. Pusat-pusat kota dapat menjadi arena kebudayaan yang menarik dimana komunikasi terjadi antara anggota-anggota ko-budaya (coculture) yang berbeda. Ko-Budaya yang dimaksud adalah kelompok-kelompok individu yang merupakan bagian dari kelompok kebudayaan besar---tetapi berbeda dalam hal ras, etnis, orientasi seksual, agama, dan sebagainya----dan menciptakan kesempatan bagi diri mereka sendiri. Mengacu kepada pendapat Gonzales, Houston, \& Chen (2004), West memaknai budaya sebagai "komunitas makna dan sistem pengetahuan bersama yang bersifat lokal" (West \& Turner, 2012: 42-43).

Dalam konteks ini, multikultural memiliki kedekatan makna dengan lintas budaya, karena multikultural sejatinya berakar pada kultur. Abdullah (2014: 99) merangkum catatan M. Ainul Yakin yang menyebutkan sejumlah definisi kultur, yaitu: Elizabeth B. Taylor (1832-1917) yang mengartikan kultur sebuah budaya yang universal bagi manusia dalam berbagai macam tingkatan yang dianut oleh seluruh anggota masyarakat. Durkheim (18581917) menjelaskan bahwa kultur adalah sekelompok masyarakat yang menganut sekumpulan simbol-simbol yang mengikat didalam sebuah masyarakat 
untuk diterapkan. Stephen Tyler (1932) mendefinisikan kultur sebagai sebuah alat untuk mengatur mental yang dapat menentukan bagaimana seorang anggota sebuah kelompok masyarakat memahami dunianya. Cliffort Geetz (1926) berpendapat bahwa kultur adalah sebuah cara yang dipakai oleh semua anggota dalam sebuah kelompok masyarakat untuk memahami siapa diri mereka dan untuk memberi arti pada kehidupan. Tim Antropologi Universitas Indonesia sebagaimana disebut Abdullah, menegaskan bahwa multikultural menunjuk pada fakta keragaman, sementara multikulturalisme menunjuk pada sikap normatif atas fakta keragaman itu. Multikulturalisme adalah pemahaman dan cara pandang yang menekankan interaksi dengan cara memperhatikan keberadaan setiap kebudayaan sebagai entitas yang memiliki hak-hak yang setara. Dari konsep inilah kemudian muncul gagasan normatif mengenai kerukunan, toleransi, saling menghargai perbedaan dan hak masing-masing kebudayaan suatu bangsa (Abdullah, 2014: 99-100).

Berdasarkan definisi tersebut diatas komunikasi multikultural bisa dikatakan sebagai komunikasi diantara orang-orang yang memiliki keragaman budaya. Untuk memahami lebih mendalam, penulis mencoba untuk mendeskripsikan definisi komunikasi multikultural tersebut kedalam sebuah kerangka sederhana agar bisa ditangkap maksudnya dengan mudah sebagai berikut:

\section{Komunikasi Multikultural Perspektif West \& Turner}

\begin{tabular}{ll}
\hline \multicolumn{1}{c}{ Dimensi } & \multicolumn{1}{c}{ Aplikasi Komunikasi Multikultural } \\
\hline Sosial & Komunikasi multikultural melibatkan dua orang (atau lebih) \\
& beragam budaya yang berinteraksi dengan heterogenitas niat, \\
& motivasi dan kemampuan. Situasi ini bisa disebut seperti \\
interaksi sosial multikultural. & \\
Proses & Komunikasi multikultural bersifat terus berkelanjutan \\
& berkesinambungan dan tidak memiliki akhir dengan proses \\
& yang dinamis, kompleks, dan senantiasa berubah sesuai \\
dengan kemajemukan kultur yang ada. & \\
Simbol & Komunikasi multikultural melihat simbol sebagai sebuah \\
& label arbitrer atau representasi dari fenomena budaya yang \\
& beragam. Simbol konkret merupakan simbol yang \\
& merepresentasikan objek budaya dengan keberagamannya, \\
& sedangkan simbol abstrak merepresentasikan sebuah ide atau \\
pemikiran budaya yang beragam. & Komunikasi Multikultural memaknai pesan dari individu- \\
Makna & individu yang beragam budayanya. Dengan keragaman kultur, \\
& maka beragam pula makna yang dilahirkan sehingga dapat \\
& menyulitkan membahasakannya. Dengan memahami makna \\
& multikultural, diperlukan pembahasan yang sama ketika orang \\
& multikultural menginterpretasikan suatu kejadian yang sama. \\
& Komunikasi Multikultural memahami lingkungan dengan \\
\hline
\end{tabular}


Kun Wazis, Komunikasi Transbudaya Pondok Pesantren: Kajian Teoretis Dalam Paradigma..

\begin{tabular}{ll}
\hline Dimensi & \multicolumn{3}{c}{ Aplikasi Komunikasi Multikultural } \\
\hline & keragaman budaya sebagai situasi atau konteks dimana \\
& komunikasi terjadi. Elemen lingkungan multikultural bisa \\
& berwujud waktu, tempat, periode sejarah, relasi, dan latar \\
& belakang orang-orang yang memiliki keragaman budaya.
\end{tabular}

Sumber: Diolah Penulis, 2017.

\section{B. Kajian Komunikasi Transbudaya Pesantren}

Kajian maupun penelitian terhadap fenomena komunikasi pondok pesantren di Indonesia sudah banyak dilakukan. Hal ini disebabkan posisi penting pondok pesantren dalam melakukan perubahan sosial di masyarakat. Tiga jurnal yang menjadi kajian dan penelitian para akademisi menyebutkan peran penting pondok pesantren dalam mengembangkan komunikasi transbudaya melalui pendidikan multikultural yang diterapkan pesantren. Pertama, Jurnal Ta'dib, yakni Jurnal Pendidikan Islam yang diterbitkan Fakultas Keguruan dan Ilmu Pendidikan Universitas Islam Negeri (UIN) Raden Patah Palembang dengan ISSN: 1410-6973 dan jurnal electronic (e) E-ISSN: 2443-2512 (2015). Dalam tulisan Phaosan Jehwae berjudul "Dilema Bahasa Melayu sebagai Bahasa Pengantar Pembelajaran di Pondok Pesantren Pattani Thailand Selatan" memberikan gambaran tentang peran pesantren dalam mempertahankan identitas bahasa Melayu sebagai simbol budaya masyarakat Thailand Selatan (Jehwae, 2014: 269-270). Kajian ilmiah yang dimuat pada Vol. 19 No. 2 Edisi November 2014 halaman 265-278 memberikan gambaran bahwa pesantren menjadi sarana komunikasi antarbudaya melalui identitas bahasa yang berbeda dengan bahasa resmi negara, yakni bahasa Thai. Pandangan tentang bahasa Melayu yang dipertahankan di tengah pertarungan bahasa Thailand merupakan contoh bahwa pesantren memiliki kepedulian dalam menjaga identitas budaya yang berbeda di Thailand, yakni menjaga agar bahasa Melayu tidak hilang akibat dominasi bahasa Thai yang ditetapkan pemerintah Thailand. Tema tulisan pondok pesantren di Thailand dimaksudkan untuk memberikan gambaran bahwa realitas pondok pesantren tidak hanya tersebar di Indonesia saja, tetapi juga di luar negeri dengan karakteristiknya yang berbeda-beda. Dalam hal ini, kultur pondok pesantren dapat dipahami kehadirannya di tengah-tengah masyarakat Asia sebagai bentuk komunikasi lintasbudaya (cross culture).

Kedua, Jurnal Istiqra adalah jurnal penelitian ilmiah yang diterbitkan IAIN Palu dengan ISSN : 2338-025X EISSN : 2477-1759 (2015). Dalam tulisan Jihan Abdullah, dosen FTIK IAIN Palu berjudul "Pendidikan Islam Multikultural di Pesantren: Studi Kasus pada Pondok Modern Ittihadul Ummah Gontor Poso" tersebut memberikan gambaran bahwa dunia pondok pesantren sejatinya tidak asing dengan persoalan komunikasi lintas budaya. Tulisan dalam jurnal Vol. 2 No. 11, 
Edisi 1 Januari-Juni 2014 halaman 95123 tersebut mengungkapkan beragam perbedaan budaya yang bisa dipahami secara arif oleh kultur di pondok pesantren, baik yang salaf maupun yang modern sekalipun. Hanya saja, tidak menggambarkan interaksi sosial para santri dalam kehidupan dalam lingkungan pondok pesantren ketika berkomunikasi dengan santri-santri yang berbeda budaya. Hal ini memberikan gambaran tentang pendidikan Islam Multikultural di Pesantren yang dapat hidup di kawasan Poso yang karakteristiknya sama dengan sistem dan manajemen Pondok Modern Darussalam Gontor Ponorogo yang berada di Jawa Timur. Fenomena tersebut merupakan bentuk transformasi kultur pesantren modern di Jawa Timur, yang kemudian dibangun dan didirikan modelnya di Sulawesi.

Ketiga, jurnal Kawistara, Jurnal Sosial dan humaniora yang diterbitkan Sekolah Pascasarjana Universitas Gadjahmada dan tercatat terakreditasi Dikti No. 04. /P / 2014 dengan ISSN: 2088-5415 dan ISSN Online: 23555777 (2015). Kajian Dalmeri dengan judul "Wacana Pendidikan Islam Multikultural untuk Keharmonisan Hidup Berbangsa" yang dimuat di Vol. 5 No. 1, 22 April 2015, halaman 80-91 tersebut menjelaskan bahwa pendidikan multikultural dapat diterapkan pada era reformasi di bidang pendidikan Islam serta pendidikan yang menanamkan kepada peserta didik akan pentingnya nilai-nilai dan keyakinan yang diyakini keunikannya pada setiap etnis, budaya, dan kelompok sosial lainnya. Dalmeri menyodorkan sebuah arena solusi terhadap keberagaman etnis, budaya, tradisi, kelompok sosial, agama melalui Pendidikan Multikultural di Indonesia dengan mengambil salah satu latar Pondok Pesantren sebagai pengembangan pendidikan Islam Multikultural tersebut. Dengan demikian, pandangan dalam Jurnal Kawistra ini memiliki korelasi yang positif dengan Pendidikan Islam Multikultural di Pesantren pada Jurnal Istiqra IAIN Palu dan dinamika kehidupan Pondok Pesantren Pattani Thailand Selatan yang mempertahankan identitas bahasa Melayu melalui institusi Pesantren. Hanya saja, kajian ilmiah ini tidak memfokuskan peran kyai dalam posisi kuasa menerapkan pendidikan multikultural di pondok pesantren terhadap para santrinya.

Realitas sejarahnya yang panjang, pesantren telah menunjukkan perannya sebagai agen perubahan (agent of change) yang mammpu merespons perkembangan modernisasi secara kritis serta mengarahkannya ke arah kehidupan yang lebih berwatak, kreatif, dan emansipatoris. Hiroko Horikoshi, seorang antropolog Jepang dalam disertasinya yang berjudul " $A$ Traditional Leadher in a Time if Change: The Kyai and Ulama' in West Java, (1976)" menegaskan bahwa kyai dan pesantren sangat berperan dalam proses perubahan sosial menuju ke arah kualitas kehidupan dan kerja yang lebih baik di lingkungan masyarakat sekitar. Selain itu, Manfred Ziemek, berasal dari Jerman yang telah menulis disertasi berjudul "Pesantren Islamische Bildung in Sozialen Wandel (1986)", juga mengatakan bahwa kepemimpinan 
Kun Wazis, Komunikasi Transbudaya Pondok Pesantren: Kajian Teoretis Dalam Paradigma..

pesantren yang moralis, terbuka, humanis, dan emansipatoris telah berhasil mengantarkan pesantren sebagai agen perubahan yang kritis dan partisipatoris terhadap arus modernisasi yang tak terelakkan lagi dalam sejarah (Dalmeri, 2015: 87).

Menurut Dalmeri, sejarah telah membuktikan bahwa keistimewaan yang berhasil dicapai oleh pesantren karena didukung oleh adanya kurikulum pendidikan pesantren yang banyak memuat paham-paham pendidikan multikultural. Pendidikan Multikultural yang diajarkan di pondok pesantren didasarkan pada sejarah panjang kehidupan Nabi Muhammad SAW yang membangun masyarakat Madinah yang dikenal dengan "Negara Madinah" dengan kondisi masyarakat yang multikultural. Masyarakatnya tidak hanya terdiri satu etnis, suku, bangsa, maupun agama; namun sangat beragam. Ada sejumlah suku dominan yang mendiami kota itu. Suku Aus, Khajraj, Qoinuqa, Quraidlah, dan Bani Nadzir. Demikian pula penduduknya menganut beragam agama: Islam, Yahudi, dan sebagian kecil Kristen Najran. Masyarakat Islam sendiri terdapat dua latar belakang, yaitu kaum imigran atau pendatang yang sebuat dengan sahabat Muhajirin (dari beberapa suku asal Mekah dan sekitarnya), dan penduduk lokal yang biasa disebut sahabat Anshar yang didominasi oleh suku Aus dan Khajraj. Dari keragaman itulah, kemudian Nabi membuat suatu kesepakatan yang mengikat antar ragam yang ada, demi membangun kebersamaan, saling hormat, dan menghargai akan hak dan kewajiban masing-masing, sehingga terjalin komunitas yang tidak hanya stabil dan harmonis tapi juga hidup saling berdampingan. Konsep negara Madinah tersebut tertuang dalam piagam Madinah yang mengandung nilai-nilai universalitas: keadilan, kebebasan, persamaan hak, dan kewajiban, serta perlakuan yang sama di mata hukum.

\section{Kajian Teoretis Komunikasi Transbudaya Pesantren}

Kehidupan dunia pesantren yang multikultural tidak bisa dilepaskan dari peran kyai dalam membangun komunikasi dengan para santrinya. Kehidupan pesantren sangat bergantung pada kepemimpinan kyai. Dengan demikian, komunikasi pondok pesantren dalam proses penyampaikan pesanpesan komunikasi transbudaya melalui pendidikan multikultural dapat dijelaskan melalui teori tindakan sosial, teori konstruktivis, dan teori fenomenologi yang ketiganya memiliki karakteristik masing-masing. Ketiga teori tersebut ketika diaplikasikan untuk mengkonfirmasi realitas komunikasi transbudaya santri melalui pendidikan multikultural dapat dijelaskan sebagai berikut.

\section{Teori Tindakan Sosial Max Weber}

Untuk menganalisis fenomena komunikasi kyai terhadap santri dalam penyampaikan

pesan-pesan multikultural dapat menggunakan Teori Tindakan Sosial yang dikemukakan Max Weber. Perilaku komunikasi multikultural antara kyai dan santri 
multikultural dalam kehidupan di lingkungan pondok pesantren dapat terkategori sebagai tindakan sosial dalam teori Weber. Menurut Weber (dalam Kuswarno, 2013: 109),, tidak semua tindakan manusia disebut sebagai tindakan sosial. Suatu tindakan hanya dapat disebut tindakan sosial apabila tindakan tersebut dengan mempertimbangkan perilaku orang lain dan berorientasi pada perilaku orang lain. Katanya, "Action with 'takes account of the behaviour on others and is thereby oriented in its course'. Social Action, then, is subjectively meaningful behaviour which is influenced by, or oriented towards the behaviour of others." Jadi, tindakan sosial merupakan perilaku manusia yang mempunyai makna subjektif bagi perilakunya. Dengan demikian, tindakan sosial merupakan perilaku subjektif yang bermakna dan ditujukan untuk mempengaruhi atau berorientasi pada perilaku orang lain.

Tindakan kyai merupakan tindakan sosial yang ditunjukkan oleh perilaku subjektif kyai dalam mempengaruhi santri ketika menyampaikan pesan-pesan multikultural dalam kehidupan pesantren. Sebagai pemimpin yang sentralistik, tindakan sosial yang dilakukan kyai merupakan tindakan yang dilakukan agar para santri berbeda budaya itu dapat tunduk dan menerima pengaruh-pengaruh pesan multikultural yang disampaikannya. Sebaliknya, santri-santri dengan latar belakang budaya yang berbeda juga akan melakukan "tindakan sosial" serupa sebagai bentuk ketaatan dalam kultur pesantren, sehingga tindakan santri tersebut akan dipahami oleh kyai sebagai pemimpin kharismatik di pesantren.

\section{Teori Konstruktivis}

Teori konstruktivis dapat digunakan untuk membaca realitas sikap santri multibudaya dalam memaknai pesan yang di komunikasikan kyai dalam aktivitas pendidikan multikultural di pondok pesantren. Teori konstruktivis atau konstruktivisme dinilai sebagai makna yang sama. Sebagai sebuah teori, menurut Littlejohn (2014: 25), konstruktivisme percaya bahwa orang yang menciptakan pengetahuan agar dapat berjalan secara pragmatis di dunia---bahwa fenomena dapat dipahami dalam cara yang berbeda dan sempurna---dan bahwa pengetahuan adalah apa yang dihasilkan dari seseorang di dunia ("mereka bukan apaapa hingga saya menyebutkannya"). Akhirnya membawa konstruktivisme selangkah lebih jauh, konstruktivisme sosial mengajarkan bahwa pengetahuan merupakan produk interaksi sosial simbolis dalam kelompok-kelompok sosial. Dengan kata lain, kenyataan terbentuk secara sosial, sebuah hasil kehidupan kultural dan kelompok. Berdasarkan definisi tersebuti, teori konstruktifis menjelaskan dua hal penting. Pertama, bahwa setiap manusia menciptakan pengetahuannya sendirisendiri agar mereka dapat hidup di dunia. Kedua, pengetahuan yang didapatkan tersebut untuk bertahan hidup itu sejatinya bukanlah hasil kreasinya sendirinya, melainkan hasil 
Kun Wazis, Komunikasi Transbudaya Pondok Pesantren: Kajian Teoretis Dalam Paradigma..

dari interaksi sosial dengan orang lain, yakni kehidupan kultural dan kelompok yang mempengaruhi seseorang tersebut bertindak. Untuk mempertegas teori ini, Littlejohn mencontohkan sebuah kasus wasit, pengetahuan tentang apa itu bola dan pukulan hanya dapat diketahui dalam kerangka permainan baseball, serta dalam kedua istilah tersebut, bola dan pukulan memiliki banyak arti lain dalam bahasa Inggris yang cukup berbeda dalam permainan baseball Littlejohn (2014: 25).

Dalam kehidupan masyarakat pesantren, para santri multikultural itu menciptakan pengetahuan yang dimiliki selama mereka hidup di pesantren agar mereka dapat hidup di dunia pesantren. Kemampuan dirinya menjadi salah satu cara untuk bertahan dalam lingkungan yang berbeda dengan sebelumnya. Interaksi sosial dengan santri lain yang berbeda budaya ikut mempengaruhi pengetahuan yang dihasilkannya tersebut. Kehidupan pesantren dengan keragaman budaya tersebut menjadi alasan mereka bertindak agar eksistensinya dirinya tidak tergusur. Peran sentralistik kyai yang dominatif juga ikut membentuk pengetahuan para santri, termasuk cara bersikap santri terhadap pesan-pesan komunikasi multikultural yang disampaikan kyai dalam kegiatan pendidikan multikultural di pesantren tersebut.

Menurut Litlejohn (2014: 179182), konstruktivisme adalah sebuah teori yang dikembangkan oleh Jesse Delia dan koleganya yang mengatakan bahwa individu menafsir dan bertindak menurut kategori konseptual yang ada dalam pikiran. Realitas tidak menghadirkan dirinya dalam bentuk kasar, tetapi harus disaring melalui cara seseorang melihat sesuatu. Konstruktivisme mengenai bahwa gagasan memiliki asal mula sosial dan dipelajari melalui interaksi dengan orang lain. Selanjutnya, budaya terlihat sangat penting dalam menentukan makna kejadian. Kebudayaan dapat mempengaruhi cara-cara tujuan komunikasi ditetapkan, bagaimana tujuan dicapai, seperti jenis-jenis gagasan yang digunakan dalam skema kognitif. Konstruktivisme sebagian didasarkan pada teori George Kelly tentang gagasan pribadi yang menyatakan bahwa manusia memahami pengalaman dengan berkelompok serta membedakan kejadian menurut kesamaan dan perbedaannya. Perbedaan yang dirasakan tidak akan terjadi secara alami, tetapi ditentukan oleh hal-hal yang bertentangan dalam sistem kognitif individu. Pasangan yang bertentangan, seperti tinggi/ pendek, panas/ dingin, dan hitam/ putih, yang digunakan untuk memahami kejadian dan banyak hal, disebut gagasan pribadi. Gagasan ini merupakan sumber nama dari teori Kelly---teori gagasan pribadi.

\section{Teori Fenomenologi Alfred Schutz}

Teori berikutnya Teori Fenomenologi dikembangkan Alfred Schutz, seorang sosiolog kelahiran Vienna tahun 1899, yang merupakan hasil dari kritikan Scutz terhadap pemikiran Weber dan Husserl tentang 
sosiologi. Schutz setuju dengan pemikiran Weber tentang pengalaman manusia dan perilaku manusia (human being) dalam dunia sosial keseharian sebagai realitas yang bermakna secara sosial (social meaningful reality). Schutz (Kuswarno, 2013: 109) menyebut manusia yang berperilaku tersebut sebagai "aktor". Ketika seseorang melihat atau mendengar apa yang dikatakan atau diperbuat aktor, dia akan memahami (undestand) makna tindakan tersebut. Dalam dunia sosial, hal demikian disebut sebagai sebuah "realitas interpretif" (interpretive reality).

Bagi Schutz dan kaum fenomenologis, tugas utama analisis fenomenologis adalah merekonstruksi dunia kehidupan manusia "sebenarnya" dalam bentuk yang mereka sendiri alami. Realitas dunia tersebut bersifat intersubjektif dalam arti bahwa anggota masyarakat berbagi persepsi dasar mengenai dunia yang mereka internalisasikan melalui sosialisasi dan memungkinkan mereka melakukan interaksi atau komunikasi. Schutz setuju dengan argumentasi Weber bahwa fenomena sosial dalam bentuknya harus dipahami secara tepat. Schutz juga bukan hanya menerima pandangan Weber, bahkan menekankan bahwa ilmu sosial secara esensial tertarik pada tindakan sosial (social action). Konsep "sosial" didefinisikan sebagai hubungan antara dua atau lebih orang dan konsep "tindakan" didefinsikasn sebagai perilaku yang membentuk makna subjektif (subjective meaning). Akan tetapi, menurut Schutz, makna subjektif tersebut bukan ada dalam dunia privat, personal dan individual. Makna subjektif yang terbentuk dalam dunia sosial oleh aktor berupa kesamaan dan kebersamaan (common and share) di antara para aktor. Oleh karenanya sebuah makna subjektif disebut sebagai "intersubjektif".

Makna intersubjektif dunia sosial, menurut Schutz (dalam Kuswarno, 2013: 109-110), harus dilihat secara historis. Oleh karenanya, dia menyimpulkan bahwa tindakan sosial adalah tindakan yang berorientasi pada perilaku orang atau orang lain pada masa lalu, sekarang dan akan datang. Schutz menjelaskan bahwa melihat kedepan pada masa yang akan datang (looking-forward into the future) merupakan hal yang esensial bagi konsep tindakan atau Action (handeln). Tindakan adalah perilaku yang diarahkan untuk mewujudkan tujuan pada masa datang yang telah ditetaokan (determinate). Kalimat tersebut sebenarnya mengandung makna juga bahwa seseorang memiliki masa lalu (pastness). Dengan demikian tujuan memiliki elemen ke masa depan (futurity) dan elemen masa lalu (pastness). Untuk menggambarkan bahwa tujuan suatu tindakan sosial seseorang cukup kompleks, Schutz meminjam istilah tata bahasa, dengan menyebut in the future perfect tense (modo tuturi exact).

Dalam konteks dunia pesantren, santri adalah aktor yang melakukan tindakan sosial (menuntut ilmu, termasuk pendidikan multikultural) bersama santri berbeda budaya lainnya dalam lingkungan pondok pesantren yang dipimpin seorang kyai sehingga 
Kun Wazis, Komunikasi Transbudaya Pondok Pesantren: Kajian Teoretis Dalam Paradigma..

diantara para santri memiliki kesamaan dan kebersamaan dalam ikatan makna intersubjektif. Para santri tersebut juga memiliki historisitas dan dapat dilihat dalam bentuk alami di dunia pondok pesantren, tempat mereka menuntut ilmu. Dengan demikian, santri juga bisa saja memiliki motif diantara dua motif ketika mereka menjalani kehidupannya sebagai santri yang berlatar belakang budaya berbeda, baik berorientasi pada masa lalu maupun masa yang akan datang. Motif yang dipilihnya akan menentukan penilaian terhadap dirinya dalam statusnya sebagai santri yang memahami perbedaan budaya sebagai sunnatullah (sesuatu yang pasti ada), bukan keburukan.

\section{KESIMPULAN}

Berdasarkan kajian pustaka dan kajian teoretis terhadap komunikasi transbudaya pesantren melalui pendidikan multikultural dapat disimpulkan sebagai berikut.

1. Komunikasi transbudaya di lingkungan pondok pesantren sudah sejak lama dilakukan karena para santri yang mendalami ilmu di pesantren berasal dari latar belakang budaya yang berbeda.

2. Para santri mengembangkan sikap saling memahami terhadap perbedaan tersebut sebagai suatu sunnatullah yang tidak dipertentangkan sehingga dapat menjalin komunikasi yang baik selama belajar di pondok pesantren.

3. Posisi kyai memiliki kedudukan yang tinggi dalam membangun komunikasi dengan santri ketika menyampaikan pesan-pesan mengenai perbedaan budaya yang harus dipahami oleh sesama santri.

4. Pendidikan multikultural yang dilakukan pondok pesantren menjadi modal penting dalam membentuk santri yang memahami pluralitas sebagai sesuatu yang wajar, bukan sesuatu yang bertentangan.

5. Ajaran Islam rahmatan lil alamin yang diajarkan di pondok pesantren menjadi pesan-pesan penting dalam memaknai perbedaan budaya sebagai kekuatan, bukan kelemahan para santri.

\section{DAFTAR PUSTAKA}

Abdullah, Jihan. 2014. Pendidikan Islam Multikultural di Pesantren, Palu: Jurnal Istiqra.

Dalmeri. 2015. Wacana Pendidikan Islam Multikultural untuk Keharmonisan Hidup Berbangsa. Yogyakarta: Jurnal Kawista.

Jehwae, Phaosan. 2014. Dilema Bahasa Melayu sebagai Bahasa Pengantar Pembelajaran di Pondok Pesantren Pattani Thailand Selatan. Palembang: Jurnal UIN Raden Patah.

Littlejohn Stephen W. \& Karen A. Foss. 2014. Teori Komunikasi (Jakarta: Salemba Humanika.

Kuswarno, $\quad 2013$. Fenomenologi, Bandung: Widya Padjadjaran. 
Mulyana, Deddy. 2014. Ilmu Komunikasi: Suatu Pengantar, Bandung: Remaja Rosdakarya.

Pujileksono, Sugeng. 2015. Metode Penelitian Komunikasi Kualitatif. Malang: Instrans Publishing.

Samovar, Larry A \& Ricard E. Porter, dan Edwin R. Mc Daniel. 2014. Komunikasi Lintas Budaya. Jakarta: Salemba Humanika.

Sendjaja, Sasa Djuarsa. 2011. Teori Komunikasi, Jakarta: Universitas Terbuka.
West, Richard \& Lynn H. Turner. 2012. Pengantar Teori Komunikasi: Buku 1, Jakarta: Salemba Humanika.

\section{INTERNET}

http://jurnal.radenfatah.ac.id/index.php/t adib, diakses 27 November 2015. http://jurnal.iainpalu.ac.id, diakses 27 November 2015.

http://jurnal.ugm.ac.id/kawistara/article/ view/6407/5055, diakses 27 November 2015 . 